\title{
Art and Life in Security Context
}

\author{
${ }^{1}$ Ogunfuwa, Timothy Olusola, ${ }^{2}$ Oladugbagbe, F. E. Allan and \\ ${ }^{3}$ Emeriewen, Osevwiyo Kingsley \\ ${ }^{1,2}$ Fine and Applied Arts Department, Ladoke Akintola University of Technology, \\ LAUTECH, Ogbomoso, Oyo-State, Nigeria \\ ${ }^{3}$ Fine and Applied Arts Department, University of Benin, Benin City, Edo State, Nigeria
}

\begin{abstract}
The arts have functionally intertwined with almost every facet of human lives-the most obvious being in the socio-cultural and religious aspects. In the more remote periods and ages, the arts (essentially dance and performance, storytelling and poetry recital, and body painting and object carving, and many more) are usually tailored towards securing politically and economically stabled community. Thus, the arts have been important tool in the sustenance and preservation of human existence and the creative recourse has dated to prehistoric times, when life and security sustainability was equally measured in terms of artistic representation of experiences. From the genre of the arts, the visual arts have steadily grown in their importance to human sustainability on earth. Moreover, art and life have become inseparable in the understanding of human evolutionary processes and security, but the arts have not enjoyed much attention in literary domain in its provision as security to life and property. This essay, therefore, discusses particularly the visual arts as major signpost in human security context, illustrating with instances and materials, forms and types of the fine and applied arts that serve as security tools across different ages and peoples. It shows that religion, art and architecture has all the while been inseparable trio in our determination of security of life and property, and that advancement in modern technology has also assisted in blurring functional distinctions earlier known among art, religion, spirituality and architecture.
\end{abstract}

Key Words: Art, Security, Life

\section{Background}

The signification of arts is wide: both in the literary and visual senses. The characteristics and attributions of arts are also wide. Fifty years ago, Weiss (1961: 7) classified architecture, painting, sculpture, music (composition and performance), stories, poetry, theatre and dance as the basic arts. But within and beyond this period, many other aspects of the creative arts have been well and worthily recognized. Some of these are pottery and ceramics, graphic design, textile, drawing, and some other creative adventures and objects that found themselves into the museums or that are publicly described and recognized as creative arts. Foremost of some of these objects are moveable objects like traditional religious, cultural and purely decorative objects; and immovable objects like the Mbari houses and the giant pyramids of Egypt. The traditional presentations and incentives of most of these objects are not foremost artistic (though they are creative in their form and material), but religious and protective.

For instance, the giant pyramids - "castles of eternity"-which secondarily served as final resting place of the physical being of kings (Gombrich, 1985: 32), primarily served as kings' souls' refectories for the consummation of the security meal of spiritual ascension to "heaven" and for the kings' alignment with the immortality of gods of their fatherland. These "architectural" objects or monumental tombs - the pyramidshave in addition to their importance been considered by archaeologists, art historians and anthropologists as marvels of artistic actualization (Malek, 2006; Boorstin, 1992: 156-163; Segy, 1969: 29). The objects, including the Great Sphinx at Giza, with their extensive security apparatuses and undertones, are actually symbols of the height of man's association with the security of "life" of the dead after an earthly transition - an imminent association with the gods.

On other the hand, the Mbari houses (and their accompanying sculptures) of the Owerri Igbo clan are erected for Ala, the earth goddess. Egonwa (2011: 61-62) notes further that, appeasing this goddess regularly from this creatively built abode will wade off evil and the growth of the community will be assured. In essence, the artistic adventure is primarily directed towards the sustenance of life, towards the earthly population of the Owerri people. All traditional African societies take security of lives and properties seriously and approach this resolution mostly through religio-magical means similar in context to the Egyptian and Owerri people, but not necessarily in their form.

Interestingly, as many of these highly creative movable religio-magical objects found way into the museums, they began to be publicly described and recognized as creative arts. However, the modern and 
postmodern implication and attribution of constituents of some of these and some other ascribed creative arts is sometimes vagaries and irreconcilable. But two important things, though, that bond all arts together as eternal contribution to mankind are their capability to entertain and at the same time to disseminate some kind of knowledge. In addition to these functions, the fine and applied arts (and admittedly architecture) also have the capability to decorate. All together, when these functions are viewed from a broader scope of their affective psychological, socio-cultural and historical importance, then the arts, in several other instances, also serve to secure our existence, even since the ages past.

Security has been regularly employed by human to guaranty the growth of human society in every geographical location. Security application comes in different forms, depending on what are the threats and what are being threatened. The threat can be man-made, natural disaster or even wild beasts. Thus, as we develop, our sense of protection against these hazards also improves; and, ultimately, our creative impulse towards achieving this security goal also gets intensified. A brief narration of security means man and society have employed along historic times will amplify an understanding into this early consciousness towards protecting human lives.

Early human families in Africa and other parts of the prehistoric world used the caves as homes and to protect themselves against animals and sometimes bad weather (Gombrich, 1985: 20). Though the innermost parts of the caves were reserved for artistic representations and presentations of their hunting escapades, they were also assumed to serve as reverential corners for ritual magic (Adepegba, 1995: 1-6; Egonwa, 2005: 134137; Gardner, 1980: 25). As these families grew in size, they had to extend their search beyond immediate enclaves. As they searched, many families undoubtedly became nomadic in the process. They built tents as they moved. As they grew even larger and had to amass food items, cultivate the land and rear herds, logically they started building permanent huts and had to secure reasonable land area for their families-immediate and extended. Presumably as they got wiser, they formed into communities. The need for protection against wild preys and human invasions became inescapable. Fortification of land areas around shelters by some of these early communities have been recorded (Sitwell, 1964).

Invariably, as the wants of man grew insatiable, the horizon for his search for attainability also expanded; his accessible environment also increased. The very interesting thing about community expansion was the natural creation or development of feudalism. Acquisition of land areas by lords and kings became an increasing appetite. Wars arising through this medium also became inescapable. Weapons of war were largely armour, shield, arrow, spear and sword. The stamping of authority over particular land and people of distant acquisition needed surveillance and they also needed to be in touch with their lord and master. Therefore, the king's messenger en route these lands was an armed courier. He was emblazoned with the insignia or staff of office of his lord and master to distinguish him and as well pin him to his master-lord. These insignias, since this period, became seals of ascription, authority and identification; they became creative properties of different dynasties recorded in histories of many kingdoms (Oliver, 1991). In Western Europe, the prestige of kings and knights (the religious crusaders) was crafted out from the heraldic symbols that were creatively and sometimes painstakingly emblazoned on the ornaments of war (plate 1).

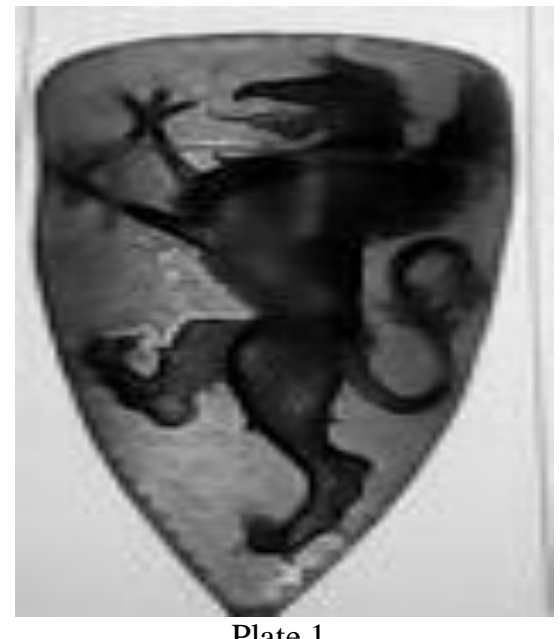

Plate 1

A 15 th century ceremonial shield with Florentine workmanship Oliver, Stefan (1991: 23). An Introduction to Heraldry.

Then heraldry, which is largely exemplified in the protective iron shield of war, Oliver notes further, was born. It has its origins in warfare and stems from the warrior's primitive desire to display an emblem in battle to strengthen his own morale and strike terror into the heart of his enemy. All over the world and all 
through history examples of this kind of decoration can be found. As soon as man was able to grasp the advantage to be had from using a weapon to hit or pierce his foe, he had also to develop a shield to protect him from retaliation. The large surface thus provided was the ideal vehicle for military decoration (1991: 10).

As we began to protect our lives and properties, we also thought of protecting our spiritual entities. The time that man began to believe in the supernatural is as old as the undeterminable period of the beginning of language and art. Most of the objects of his spiritual service were revered tools and were artistically created. Many are still are. Since the prehistoric times, therefore, architecture, religion and art have existed together, with one or two, most times, influencing the component structure of the other. The fact that the three survive through the ages and still blossom today is an objective pointer to the structural and protective importance of their usage.

As shelter becomes one of our most sought preference-at least, as our first means of protection and security - we thereafter search for means of elongating our existence and survival. We regularly put our soul or the subconscious to task to search for the superhuman protection; the super structure that is all-knowing and allprotective. This most sought knowledge, though acquired and exhibited in varying forms in different people and communities of the world, is also a most unique, universal phenomenon. Religion, as it were, becomes the second strongest security for a person's special survival; that is, in the afterlife. Creative arts and their physical objects of creativity have severally been employed as a means to process the ultimate goal of afterlife.

Thus, "art for life's sake" becomes essentially important in the actualization of the art in the security of human existence (Atmore, Stacey and Forman: 105-125). More important, however, the applied arts will fit well into the mainstream of the arts appropriateness in security devices and security secondary tools. For instance, many of the traditional African art seem to be fine art, when ordinarily assessed from their face value, more especially when they have been displayed in foreign museums as the arts of some particular African people. The associated functional importance, most times, have been derided. But many foreign African art historians and ethnographers now know otherwise, but still would not be undisturbed by their being displayed in the art or ethnographic museums. It is now a general knowledge that most of these sculptures and found objects were, first and foremost, applied arts; many were originally used as security items for protecting human lives.

All this being as it may, the application of art, especially drawing, sculpture and architecture, in the survival and sustenance of African communities has been widely documented. Most of these documentations have been dedicated to traditional religio-magical art forms. A sense of extension in the application of arts to the security of contemporary life settings need also to be occasionally examined. This will further accentuate the allencompassing importance of the creative arts - in all their possible classifying ramifications - in the pursuance of a perpetual human existence on earth. Accomplishing this exercise, though peripherally, will be the remaining focus of this paper. But it is the embodiment of creative arts in the broad socio-economic and religiopolitical lives of a few West African nations (ancient and modern) that will be examined, again with the aim of accentuating the importance of drawing and modern graphic design, metal and wood works, and craft as peculiar security apparatuses that have helped continued human existence.

\section{Art in Security of Human Spirituality and Personality}

Security tools need not necessarily have design or pattern on them, in order to be efficacious. The simple fact that some of them have is a testimony to the positive attenuation of its being added. This, at least, could be for aesthetic reason. In this case, many examples abound, even from time past. Sculptors in the Benin kingdom in Nigeria could be acknowledged to be great designers as well, because of the intricate ornamentations they introduced into most of their works. This may not be unconnected with the love of the Benin people for social grandiose on the one part and the artists' attachment to king's and nobles' courts on the other. The ivory salt cellar (plate 2) is a typical example of such flair.

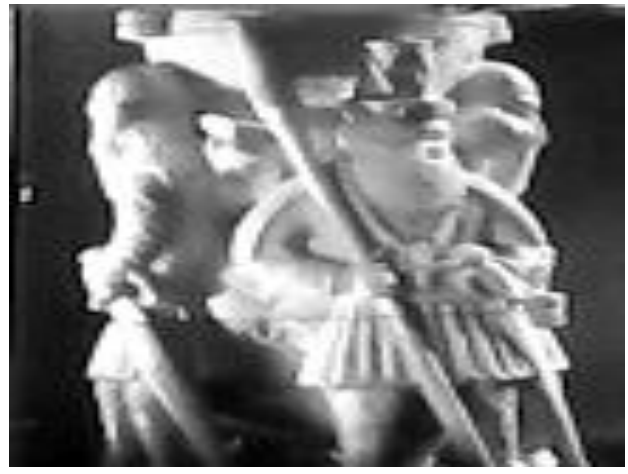

Plate 2

A 16th century Ivory salt cellar

Atmore, A and Stacey, G. (n.d: 15) Black Kingdoms Black Peoples. 
The ivory work, because of the peculiarity of the subject matter, has been dated as not earlier than around the 16th century (Atmore, Stacey and Forman: 14). What makes it apparent that the salt cellar was not made in Benin, though it could have been done by a Benin carver (free man or slave, as suggested by Atmore, Stacey and Forman) in Portugal, is the fact that the heavy beards were peculiar to knights when it was considered a socially abhorrence by elites of the time; and that the knight in the foreground has a headgear patterned with Masonic symbols: the square and compasses and the cubs of corn. Armed with spear and dagger, and a necklace with the sign of the Red Cross round his neck, and supported with accompanying knights, show the main knight as a nobleman; a Knight Templar — the early defender of the Christian faith (Hodge, 2009). In essence, they are securing safety of lives in and around the Hold land and also defending the property of the kings wherever they domiciled. The elaborate and intricate designs put together into achieving this cellar shows the resplendence that was always attributed to the Knights Templar, which Hodge (2009) proclaims to be the most commanding and influential "military religious order" of the Middle Ages in whole of Europe (plate 3).

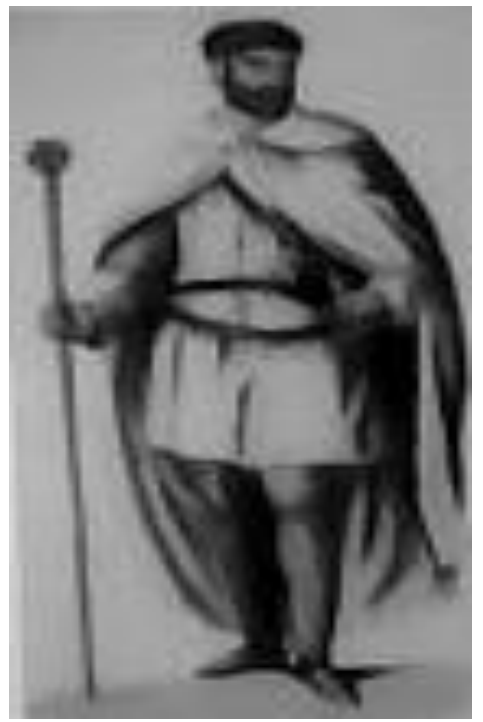

Plate 3

A Knight Templar

Hodge, Susie (2009). The Secret History of the Knights Templer.

The reoccurrence of the shield in works of art of time past is one attestation to its importance as a major defence implement. The design on it, most times, is not accidental; it is representation of the king's mark or the user's. The soldiers with shields surface in some of the Benin artefacts regularly, principally because they were court art. In similitude to the heraldic symbols or patterns in the shields of the Knights Templar, the centralized symbols on the shields of some of these Benin artefacts are sometimes different from one to the other. In one bronze plate cast around the 15th century, the two flanking warriors of a chief hunter have the symbol of a bird (probably eagle) on their shields; while on another plate cast around the same period, the two flanking warriors by the shrine or sacred gateway have the symbol showing a regular leaf shape. The symbols, as one may possibly deduce, could be the "Mark" of their goldsmiths. In many parts of the world, the use of marks as symbol of authority or legitimisation of the use of gold or silver (and in the case of the Benin metal craftsmenbronze) has been acknowledged and documented, even as far back as 1904 (Jackson, Sir; 1964).

Since the gold, silver and bronze have been precious metals, because the craft of working in these mediums have been generationally transferred among families, and because rulers have always been interested in the use and movement of these valuable metals, it is a logical approbation, as Sir Charles quotes from the Guild of London Goldsmiths, which states that the 1363 Act of legislation concerning goldsmiths required that, "every master goldsmith [as every craftsman of metal was referred to] was required to have a mark" (Jackson, 1964: 2). The introduction of marks into precious metal works has been generally considered security marks of products. While in some cases these have been hidden on these objects, in these Benin artefacts they are boldly displayed as embellishments or symbols on implements or accoutrements used by images in these artefacts. Thus, security is here amplified as creativity security, or better still as copyright, traceable to its creator. This also goes to show that symbolic drawings and patterns are highly valued by their creators; they act as protective or authenticity symbols and patterns of the craftsmen.

While drawing and pattern could be of security importance in themselves, they can as well be introduced into security apparatuses as just embellishments for aesthetic purposes. In this case, the introduction of artistic patterns or objects is merely for decorative purposes, they add no other functional means. This class of 
objects also abound among peoples of Africa. A couple of this example is the protective wrappers common among nursing mothers in West Africa (known as oja among the Yoruba of south-western Nigeria) and the Tuareg shield. The oja is used by nursing mother as additional strap to hold the baby firmer to her back. In many cases, the traditional oja is hand woven and sometime sparsely ornamented. The patterns could be geometrical but always regular.

But the Tuareg uses the intricately designed shield for fighting and hunting. The design on it is concentrated on the smoothened part of the surface of animal skin used. A close look at the pattern in the design reveals similarity in the facial scarification of the Tuareg (plate 4).

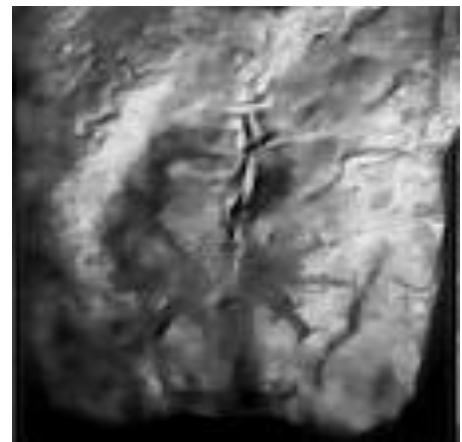

Plate 4

Tuareg shield

Atmore, Stacey \& Forman (n.d:59), Black Kingdoms, Black Peoples

While this in part suggests a link between the Tuareg and his implement of self-defence, the use of the shield in whole, as occurring in different communities, suggests its inevitability to man's survival and strength, and again a most precious item that merit arduous craftsmanship, creative attention, regular polish and approbation from its user - in order that the life span of it and its user may be prolonged on earth.

The foregoing are a few templates of the creative arts in the security of the individual. They may, by extension, also be proved to be literary alibi for an encompassing tool for the traditional society security in ages past, before the discovery of mechanical technology. It is again apparent that as people protect their lives, they also invent means of separately protecting their properties. In traditional African setting, they sometimes end up using spiritual means and objects. Again, building high, strong walls and gates in architecture have also been advantageous. But precious items such as gold dust, religious parchments, wills and handy bequests, have occasionally received greater attention for security. Various means have been devised for this-some in metal; some, wood; some, leather-all depending on the value and material of the would-be-content. And since the nature of man is mostly to show his affection for his belongings through care, he could go extra mile to beautify some of these things when opportunity or essence permit. Two examples, again, will do to illustrate this tendency.

The land of the Gold Coast is renowned for its wealth of gold, and the land had been reputed to be well traversed by merchants from Europe (wanting gold and ivory), and the Sahara and Sahel (wanting salt and other merchandise) (Davidson, 1991: 87-97). The gold and salt were two very valuable items during the trans-Sahara trade. Various precautionary measures were also adopted in transporting these items, especially the gold dust and ingots. It is, therefore, not out of place for the Akan craftsmen of Ashanti Kingdom to produce brass containers, sometimes with lids, to carry gold dust and other valuables like precious stones (plate 5)

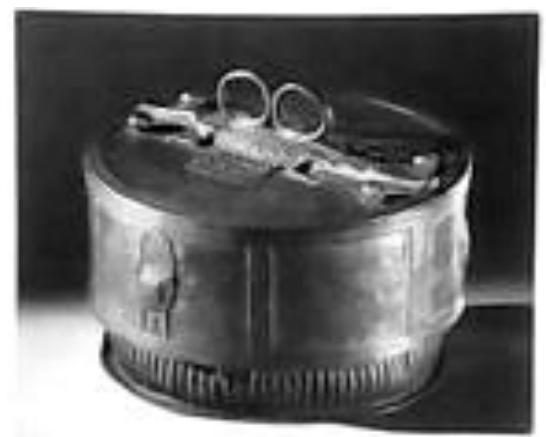

Plate 5

A Brass Container with lid (kuduo) Atmore, Stacey \& Forman (n.d: 92), Black Kingdoms, Black People 
The container, which is known as Kuduo is always well crafted and ornamented. The lid is sometimes crafted with zoomorphic ar anthropomorphic form, and engravings are limited to the edge of the lid and the lower part of container.

The importance or value given to property being secured varies from place to place and in material. The how and where most of the "Dead Sea Scrolls" were found is now common knowledge. These fragmented scrolls or codices of the Essenes (technically referred to as the Qumran Scrolls/Texts), many of which date back to the Christ era, were found in jars buried in caves around Qumran, a desert region in Palestine-all with a reason to protect their treasured works from the prying eyes of persecutors (Wise, Michael and Cook, 1999). While the jars were not primarily constructed to house the codices, they secondarily acted as make-shift banks for their treasured contents. The spiritual and religious importance of the codices at that trying time necessitated the conversion of jars to unsuspecting security items. These utilitarian works of art, including the innermost part of the caves, became the saving grace of these priced items that have apparently been projected as catalyst that may alter both the general perception of religion on the one hand, and that of the Christian faith on the other (Wise, Abegg and Cook, 1999: 34-35).

Fervent adoration of the instrument of religion is universal; preserving the instrument is also spiritually and physically mandatory. The Judaic sect revered the Torah and the codices, Christians look towards the Bible, and Mohammedans still adore the Qur'an. Because the ancient copies of most religious literatures were handwritten in scrolls and parchments, sometimes with instructive, graphic illustrations, they were preserved in containers, and in boxes like the wooden parchment boards carved in Nupe, Nigeria (plate 6).

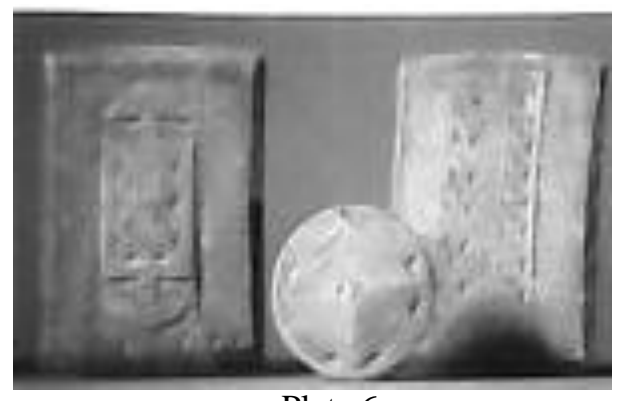

Plate 6

Panko book cover

Atmore, Stacey \& Forman (n.d: 48), Black Kingdoms, Black People

Sometimes used for encasement of Koran, these boxes or covers are known as Panko book coverderived from the native word for wood, which the Yoruba also refer to as pako.

The natural exigencies of man in view of security, as earlier noted, are to protect himself, which traditionally include his nuclear and extended families. This, by biological and environmental extension, involves protecting his physical property and surroundings. However paradoxical this may seem, the foregoing is the nature of the traditional, communal man before the scientific and technological discoveries towards his universal advancement. In many African communities, this living style still persists.

Again, the uses of works of art that are basically propitious are sometimes developed among peoples of Africa to achieve dual beneficial role for the user and family, and occasionally the community. The cult god Gu (plate 7) is abrogated the "ultimate power in life and death" among the Fon, who were known as the warrior clan of the Dahomey people. Atmore, Stacey and Cook (48-50) explain that the god takes charge of protecting the priest, worshippers and community; and also avenges for any wrong against its people and the king.

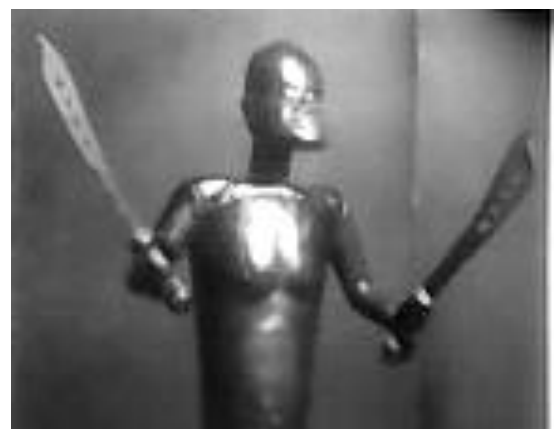

Plate 7

Fon god, $\mathrm{Gu}$

Atmore, Stacey \& Forman (n.d: 48), Black Kingdoms, Black People 
Probably it is why the god has a pair of cutlasses and looks fearsome. Apportioning celestial or sacred duties to gods is quite similar in the workings of many other cults in Africa. But while the presumed efficacy is more holistic, the import of the use of masks and masquerades is either to atone or to averse against the metaphysical world. The creative adumbration in these physical objects for spiritual connection is majorly to allow or assist human-spirit-human transformation in ceremonial performance.

Generally, after the land of a community, it is the monarchy that is held in high estimation and reverence. The monarch is the property of the kingdom, and the kingdom, his. Both, it is assumed, should jealously preserve the integrity of the other. The power of the monarch is usually metaphorically reposed in the crown and other paraphernalia of office - the crown, however, being the ultimate. Other parts of his paraphernalia include the staff, throne, beads, stool and horse tail. Crafting the crown (known among the Yoruba as ade oba) is usually reserved for the best of craftsmen in the trade, in most communities. Among the Rẹmo (Ijẹbu) Yoruba, the making of crown is occasionally commissioned to renowned a craftsman outside a kingdom, if his exemplary craftsmanship and dexterity in the art has been proven and his maturity in the handling of such sacred object can be vouched for by king's men or community priest (Ogunfuwa, 2012). And because of the sacredness of the crown, the kingdom's main crown, which is the aboriginal crown (Ade isese), for a king's coronation, is passed down to successive kings on days of their enthronement. It is usually one in the kingdom, and is therefore held with extreme caution and security. A reigning king, Ogunfuwa notes further, "is free to make additional crowns for his regular use". It is for such reason that the crown maker or craftsman, asindemade, is regular sought. Asindemade is the man who embroiders corals or gems to crown. The crown is, therefore, exceptionally valued, because in most cases the best of gems, corals metals, cloth and embroidery are used; they sometimes cost the community or king fortunes; they are culturally synonymous with the state-of-theart of the kingdom. A glimpse at the Omọnọba of Benin, the Olọwọ of Ọwọ, the Oni of Ife, or the Queen of England, during ceremonial outing will visually elaborate the importance and perception of the crown of a kingdom (plate 8).

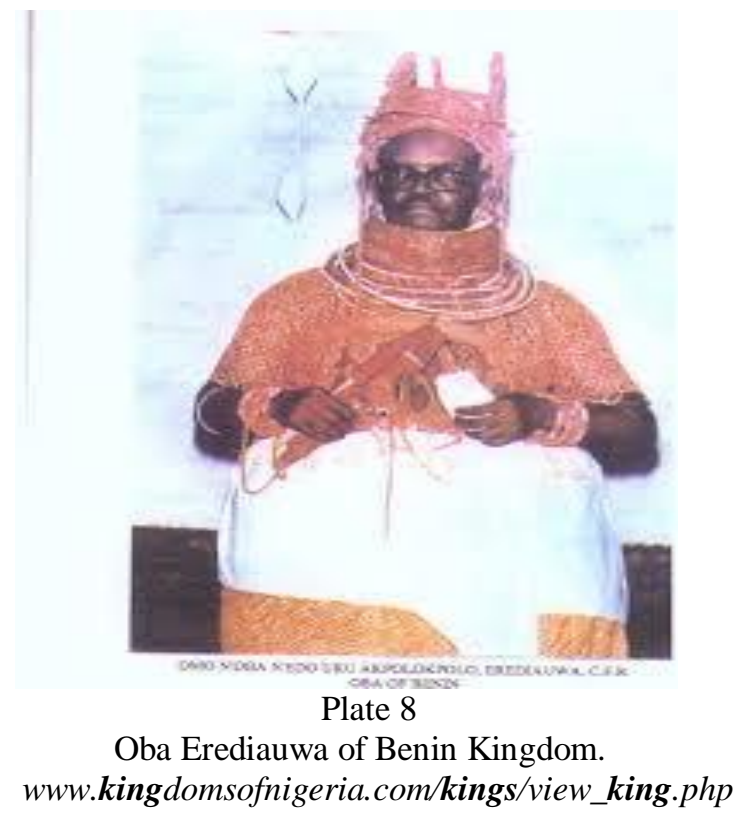

The height of creative involvement in the security of man and his environment is reserved and revered in the ade oba (crown) of his kingdom. Therefore, creative adventure, especially the visual arts, is one of the most enduring phenomena (if not the main phenomenon) ever discovered by man himself for his security.

\section{Application of Art in Contemporary Security}

The application of art in our daily lives is even broader and more encompassing in modern times. Occasionally, separating the art as utility form object of pure aesthetic appreciation is difficult. Acute, advanced technological means have propelled qualitative and quantitative production means and results. Information about happenings around the world is about the finger tips of every literate and inquisitive individual. Science, technology and creative arts are now necessary, indivisible interdisciplinary ideas that have gained audience due to cross utilization of materials and methods from these disciplines. Some new art are motorized, some are mechanized; but again, some technological devices are now admired first for their aesthetic quality. 
In recent times, therefore, many art forms become inseparable from utilities that tend to add substantial beauty. Since physical security tools are gradually detached from the spirituality of man, the physical security tools are now more entrenched and stylistically reposed in the space that lays about him; it is the unlimited tapping into the comic energy that ultimately secure his physical being-it is the adventure into the eclecticism that could be enjoyed in architecture and modern technological materials that seeks his enlivenment. The second enlivenment symbolically lies in his regularity of action in time and space, with an averting of security risks that may be caused by other users of this phenomenal emptiness, which is hidden in the power of semiotics. These two security instruments that find their usefulness in time and space of man are affective in two ways: the former is individualistic, the latter is collectivistic. They both will form the core of the subsequent illustrations.

In ancient castles, their fortification had always rested in the thick brick walls and towers. Since the age of expansion of kingdoms is over, the structure of some of these castles is now architecture mysteries of ancient civilizations. Fortification is now separated in architecture from the building itself, thus bringing the beauty in the environmental space to the fore. The fence walls begin to be slimmer and wrought iron starts playing major security role in the advancement of human life. The abundance of iron for construction and the advancement in its manipulation have particularly tended its usage in creative montage in architecture. Rather than have a regular, plain security gate, some exemplary architects and building owners now favour artistic wrought iron installations that also act as security gate for homes.

While the iron or brick-walled gate is a man's structured defence mechanism, man has also disguised himself during war, attacks and hunting. Body painting has survived from time memorial (plate 9).

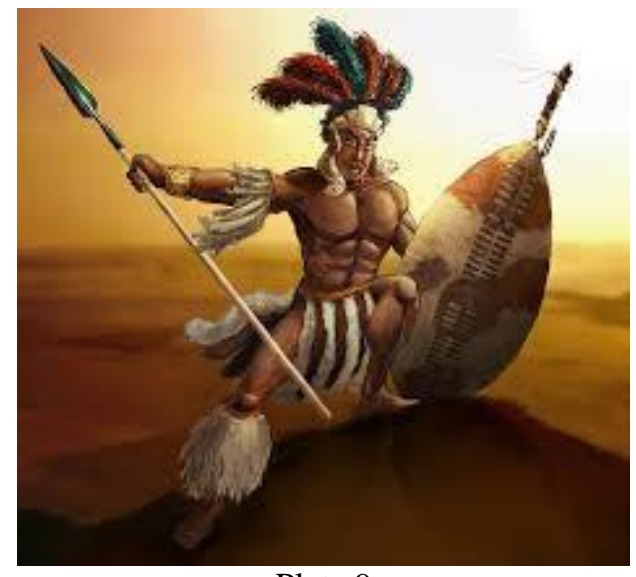

Plate 9

https://www.google.com.ng/search?biw=1366\&bih=624\&tbm=isch\&q=zulu+warrior+face\&revid=205353105

The Zulu warrior clan painted their bodies to mimic their war environments during attacks. Body painting still acts as a useful means of defence during danger and advancement of warriors in war. The sophistication of modern weapons still does not delimit the use of this simply but highly effective security device. When the uncovered parts of the body are painted to conform to the terrain of warfield and the dress worn (like the camouflage uniform of the modern-day soldier) further marches the situation, the chances of advancing without being detected is usually high. While the process of application of the paint or powder or ink is usually accompanied with fun and pranks, the careful application of the material to mimic the war terrain is always taken seriously. Body painting, which has now evolved into a fashionable and aesthetically directed course of expression called Body Art, has advanced to an enviable art form that provides economic security and livelihood to some creative people all over the world. The paint or ink medium is cheap, and the body, which is the "platform of display", is usually at no cost to the painter (Kalilu, 2013: 53). Body art, as a means of expression, has further extended to entertainment activities, more playfully to music and sports (plate 10).

In these activities, this art creates identity and personality for some popular icons, further creating avenues to sustaining these icons' economic power and socio-cultural security. This art has been able to extend impermanent colours to enrich human activities, especially football fans. National colours and club colours always create temporary spatial and mobile forms for 90 minutes in an architectural canvas that is the stadium. A sense of national or group security is usually noticed. This recent achievement of Body art as a viable means of financial sustenance has a snowballing effect on the entire society - that is, on the political stability and the socio-cultural standpoint of a people. It also shows the extent to which modernism have polished man's old ideas and reintroduce them to fit into our more demanding cultural spheres and more challenging political standpoints. 


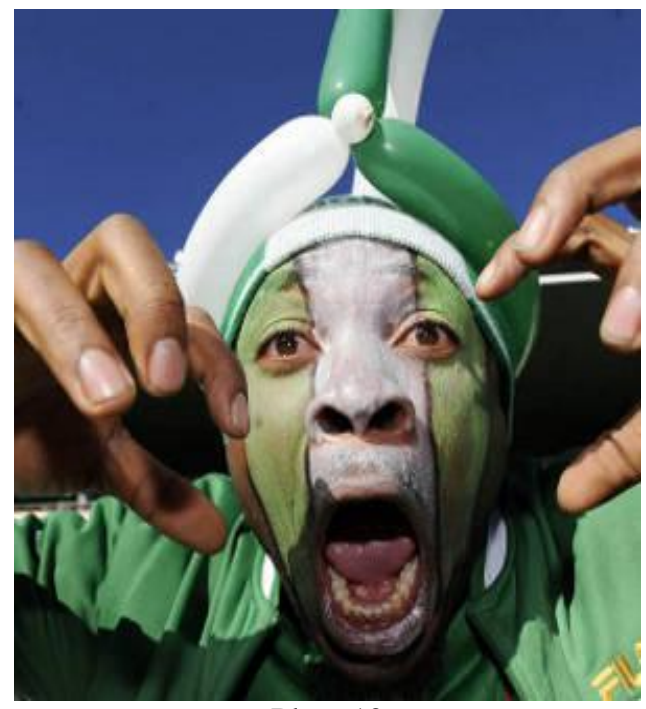

Plate 10

http://images.supersport.com/nigeria-fan-vampire-gi-300.jpg

Body art is closely in alignment of fluidity and decorativeness with the Art Nouveau, which has become a key interface in architecture and which zeitgeist is also the orchestration of spatial freedom. The Spanish architect, Cornet Y. Gaudi was renowned for this artistic attribute as exemplified in many of his Barcelona architectural works. In Nigeria, many creatively designed security wrought iron gates also abound in many homes. The Yusuf Grillo home in Ikeja, Lagos is an example of a well-crafted security gate that tells a story of how modern art could extend to contemporary living.

The ubiquity of Art Nouveau expression in architecture and security, this time around, is all over rails and guides of balconies and staircases. The designs are boundless, and in some cases truly timeless; some contemporary designs in wrought iron are mechanically produced, thereby expanding the visual allure to hypnotizing level. Decorative design motives introduced into this new creation vary from zoomorphic to anthropomorphic, biomorphic to just interplay of geometric forms. Again, the playfulness of artistic and technological marriage will be enjoyed mostly in modern, eclectic architecture.

Furthermore, the structure of the advancement in the survival of human lives is partly due to natural placement of regularly acquired and developed system of interaction-associate meanings. This is achieved through the use of created signs and symbols. Semiotic or Semiology, as the method and system of communication is evolved and produced (O'Sullivan et al, 2001: 281-283). The effective use of signs and symbols to create meaningful impact is bound by time and space. This, however, is in its broad sense of usage in linguistic and psychological imprints.

Applying this in the narrow sense of this paper, the understanding of the generated road signs and symbols, for example, actually accentuates a security of live and property based on the understanding and timely anticipating and acting to the security devices. The devices, of which signs and symbols have become universally iconic, advance with the assistance of creative graphic artists and psychologists. With time, this creation of semiotics has been standardized globally; therefore, movement of people across the globe is not in any way hampered by road signals, instructions and manuals. The creative universality of art is symbolized in the implicit consent given to security road signs by road users in many places all over the world. And how else can the greater part of lives and properties in this highly motorized and mobile twenty-first century by secured?

\section{Summary and Conclusion}

Art has helped human well-being a great deal. The security of lives and properties has either directly or indirectly been tied to the artist and its creative ingenuity. As illustrated before now, art serves human existence as utility and decorative implements or objects, even from pre-historic understanding of the human nature and its activities. As we advance in knowledge, we also explore the use of our creative acumen. The constant exploration of modern technology has, however, helped to blur further the distinct separation earlier known among art, religion, spirituality and architecture. But while it is an applauding circumstance to the general growth of mankind culturally, it also has systematically drawn back the level of appreciation of community value and the security of physical and spiritual man through extensive religious practices and spiriticism. While the effect of this latter assertion on human general growth is debatable, the elasticity in scholastic disciplines interweaving into each other has its double-sided coin effect. Nevertheless, fine and applied art has been able to creatively interlace into several facets of our lives, and when not acting in its capacity as pure aesthetic essence, 
its unavoidable string connected to the effective use of security objects cannot be structurally or wilfully undercut.

\section{References}

[1]. Adepegba, C. (1995). Nigerian Art: Its Tradition and Modern Tendencies. Ibadan: Jadad Publishers.

[2]. Atmore, A and Stacey, G. (-----) Black Kingdoms Black Peoples. Nigeria: Fagbamigbe Publishers

[3]. Boorstin, Daniel J. (1992). The Creators: A History of Heroes of the Imagination. N.Y.: Random House.

[4]. Davidson, Basil (1991). Africa in History. London: Phoenix Press.

[5]. Egonwa, Osa D. (2011). Nigerian Art: Introductory Notes. Ibadan: Ababa Press Ltd.

[6]. - - (2005). African Art: A Contemporary Source Book, Abuja: National Gallery of Nigerian Arts.

[7]. Fagg, William and Margaret Plass (1973). African Sculpture. London: Studio Vista.

[8]. Gardner H. (1980). Art through the Ages. N.Y.: Harcourt Brace Jovanovich, Inc.

[9]. Gombrich, E.H. (1985). The Story of Art. Oxford: Phaidon Press Limited.

[10]. Hodge, Susie (2009). The Secret History of the Knights Templer. London: Hermes House.

[11]. Jackson, Sir Charles James (1964). English Goldsmiths and Their Marks. N.Y.: Dover Publications, Inc.

[12]. Kalilu, R. O. Rom (2013). Art from Art for Art: Conceptualising Existence in the Space of the Visual Arts. Lagos: SOF \& Co.

[13]. Malek, Jaromir (2006). The Treasures of Tutankhamun. London: Carlton Publishing Group (Sevenoaks).

[14]. Ogunfuwa, Otunba Joseph Adediji Olafuyi (2012), Personal communication, 16 September, Sagamu in Ogun State.

[15]. Oliver, Stefan (1991). An Introduction to Heraldry. London: Quintet Publishing Limited.

[16]. Segy, Ladislas (1962). African Sculpture Speaks, N.Y.; Hill and Wang.

[17]. Sitwell, Sacheverell, intro (1964). Great Palaces. London: Weidenfeld and Nicolson.

[18]. Weiss, Paul (1961). Nine Basic Arts. Carbondale: Southern Illinois University Press.

[19]. Willett, Frank (1993). African Art: An Introduction. N.Y.: Thames and Hudson Inc.

[20]. Wise, Michael; Martin Abegg, Jnr.; and Edward Cook (1999). The Dead Sea Scrolls: A New Translation. N.Y.: HarperCollins Publishers. 